\title{
Practices in Human Resources and Employee Turnover in the Hospitality Industry
}

\author{
Nico D. Djajasinga ${ }^{1}$, Lilis Sulastri ${ }^{2}$, Acai Sudirman ${ }^{3}$, Avid Leonardo Sari ${ }^{4}$, Eko \\ Lianto Rihardi ${ }^{5}$
}

\author{
${ }^{1}$ Politeknik Transportasi Darat Indonesia, STTD \\ ${ }^{2}$ UIN Sunan Gunung Djati, Bandung \\ ${ }^{3}$ Sekolah Tinggi Ilmu Ekonomi Sultan Agung \\ ${ }^{4}$ UIN Sunan Gunung Djati, Bandung \\ ${ }^{5}$ GoAcademica Result and Publishing \\ nico.djajasinga@ptdisstd.ad.id
}

\begin{abstract}
In the hospitality sector, attrition of employees is a big global concern. The intentions of employee sales are the proxy for the current turnover of employees. The management of shifting working ties is one of the daunting challenges facing hospitality organizations. The hotel sector uses its human capital to gain its strategic edge in the consumer services market. Experts stress that the hospitality industry is a highly guest-based market that determines the enterprise's performance through meetings between staff and visitors. This analysis uses qualitative literature studies in the collection of the related data.
\end{abstract}

Keywords: Human Resources, Hospitality Industry, Employee Turnover

\section{INTRODUCTION}

One of the most rapidly developing sectors is tourism. According to the 2019 World Travel and Tourism Council (WTTC) report published by Tourism Satellite Accounting (TSA) in advance of the COVID-19 pandemic, the highest increase has been in Indonesian tourism. On the planet, Indonesia is number 9, in Asia seventh, and Southeast Asia fourth. Simultaneously, Indonesia is notable for an index of competitive tourism that has risen by eight levels from 50 in 2015 to 42 in 2017, according to the World Economic Forum (WEF). The tourism industry grew by $22 \%$ in 2019 , with Southeast Asia growing in $29 \%$ second after Vietnam (Vietnam is undergoing massive deregulation, so that it is the favorite of tourists and investors).

Krakover (2000) defines the hotel industry as an entity that offers one or more hospitality services as commonly understood, covering four sectors: hotels, restaurants, clubs, and motels. Tourism is a required field in which much human capital can be used and in which hospitality has already become a major employer (Yoety, 2008). Choi \& Dickson (2010) has shown that the hotel labor market faces two major challenges: firstly, it is challenging to draw a good workplace; and, secondly, a comparatively high turnover rate for employees suggests a substantial loss of investment in personnel, preparation, and efficiency. In comparison, the job opportunities for the hotel industry are increasing. Hotels are the world's leading employers in the tourism industry, and the high degree of mobility or turnover in this industry is a global concern. The finding of comparable employment in other firms is surprisingly straightforward for employees (Santhanam et al., 2017).

Simon \& Enz (1995) underlines that positions are widely considered unfavorable in the tourism and hospitality sector. That hotel jobs have general features of low pay and bad working conditions, a lack of job stability and opportunity for advancement, resulting in a high employee turnover. Furthermore, from his study of hotel and catering workers, Richardson (2009) presents a list of reasonably typical negative subjects in the business, such as long and antisocial working hours, low salary, low prestige, and high turnover. Employment surveys of the Ministry of Manufacturing in 2014 illustrate the second largest employer of service employees in hotels and restaurants (65.8 percent). With $20 \%$ administrative, management, management staff, $7.6 \%$ sales staff, $1.4 \%$ administrative staff, and $0.1 \%$ skilled personnel for other roles at hotels and restaurants. 
Though study on human resources practices exists extensively, few studies in the hotel industry on human resources practices exist. Similarly, much of the work seen comes from developed countries; developing countries are increasingly interested in implementing new models and systems to handle human resources that are adapted to their business contexts. The purpose of this paper is to explain the effects on psychological contracts and, in turn, the plan to settle employees in the hotel sector of human resources practices of business.

This paper first outlines the hotel industry and the particular taxonomy of the hotel industry in Indonesia in general. The next step is to analyze research patterns in organizational human resources, the psychological contract principle, and workforce turnover intentions. This paper provides a conceptual framework that harmonizes these buildings.

\section{METHOD}

Research performed using qualitative techniques for gathering critical information using literature studies. The use of qualitative designs supported by literature allows the process, which enables knowledge to be acquired using methods, which things should be considered as accurate knowledge, what is called truth, which truth criteria, and how the technical means to acquire knowledge that is about what is called truth and what is called the technique? (Anggito \& Setiawan, 2018). Qualitative conception is a test methodology that generates written or spoken words and observable behavior as descriptive facts. In other words, qualitative research is referred to as testing that does not carry out estimates. This approach aims to describe the phenomenon facing the test subjects in sentences, language, or observational behavior (Sugiyono, 2010).

\section{RESULT AND DISCUSSION}

Human resources policies have traditionally played a major part in shaping staff behaviors and behavior. Turnover desire shows a subjective likelihood of someone leaving the organization, thereby reflecting the organization's mentality. The real sales of employees is an output of expertise which can also significantly impede competition, performance, and quality distribution. Ridlo (2012) says that high-performance job activities that support employee growth, such as team promotion and employee management engagement, can improve employee satisfaction and found that this approach has a detrimental association to employee turnover. High- performing personnel practices are investing in capacity-building resources through policy procurement, training practices, integrated performance assessments, competitive incentives, and decision-making capacity that will provide workers sufficient support to do their best to serve their customers and carry out their duties effectively (Masrukhin, 2014).

Human resources programs are pathways dependent, can have a unique strategic edge, and it is impossible to recreate strategies and procedures in human resources management. Several research found an additional impact on corporate success on human resources activities (Sinambela, 2021). Catio (2020) believes that management strategies that show workers' growth and investment opportunities can decrease employee turnover. The conceptual elements of employee turnover include pay, compensation, working hours, workload, the workforce's burden, preparation and growth, leadership, job plans, and family considerations. We will explain how different human resources activities, such as recruiting, selections, training and advancement, management of success, and rewards and advantages, can affect employee leave purpose (Wahyuni et al., 2015).

Recruitment serves as the cornerstone of the company's psychological deal. Additional recruiting sources include job success, absenteeism, and attitudes. Those people who have been hired via professional conferences and apply personally (selfinitiated contacts) will have more precise and full work and organization records. Workers will also have a longer term than persons recruited by the press, college placement offices, and agency work (Rohida, 2018). It is advisable to hire staff from outlets such as references, minority recruiting, the aged and disabled and cut job sales by hiring almost everyone involved in this field. They also said that employees chosen by practical work forecasts have a lower intention to turnover (Widyantara, 2015). Realistic career predictions can improve the chances of successfully entering an individual in the psychological deal. In the selection process, further behavioral interviews were conducted, and biodata verifications were performed, but sources were not verified in other sectors as is done. They observed that inadequate internal recruiting and preparation of promoted staff resulted in intentions of high turnover. Bahri (2019) stressed that good staffing would help maintain high moral standards, as recruiting is critical in symbolic terms, apart from having the right candidates. Hotels have been described continuously as an unclear recruiting market, where hotel qualifications and recruitment requirements have not been met. In today's 
dysfunctional climate, hotel recruiters are inclined to stay and do well with the company rather than being organizationally suited for applicants chosen for a better personal organization (Arif, 2018).

Simatupang et al. (2018) observed that preparation and growth of expertise had been a major problem for many years in the hotel industry. For many factors, including the global growth of business, formal and informal training play a significant role in reducing employees' attrition, the skills and job opportunities, the regulatory standards, and improving the level of services provided to clients. They traced a major factor to the lack of well skilled and competent employees for high employee turnover in the hospitality industries. The hotel industries are a highly industrial sector that lacks job growth prospects and is undermined by staff attrition. Training on the job is the key practice in hotels, but employers do not have training from experienced workers who influence training standards. The absence of education and employment development in hotels means that workers leave their jobs (Nathalia, 2010). D'Annunzio - Green et al. (2008) found that hotels do not have well-trained staff. They emphasized the importance of preparation and development to improve front office staff capabilities in competition. She said that integrating all workers into training and increased spending in training and développement could concentrate hotel and tourism organizations. The employer and the employee should determine the psychological contract, utilizing a training relationship, what each party can give and obtain. Hotels usually see high turnover as part of the workgroup standard; workers often believe in positions with few professional growth opportunities; turnover has a large expense effect such as a lack of human capital spending, preparation, and service quality (Sharma \& Gursoy, 2018).

Performance management systems, particularly in the hospitality sector, continue to be being used increasingly. The success evaluation approach, including assessment, can be a continuous procedure used to address psychological considerations to achieve input and benefits (Ariana \& Riana, 2013). Understanding the position of the work, a fair and fair assessment, and a fair allocation of financial and nonmonetary incentives are factors that affect the contractor's performance improvement functions (Ruki, 2002). Employee levels of excellence should be related and evaluated concerning customer service practices, which are practical, feasible, and observable. Sinambela's and Sinambela's (2019) results indicate that performance assessments are mostly used for promotions, so evaluation distortions harm employee satisfaction and desire to sell. The performance evaluation process and managers' approval impact employee support behavior. Development evaluations, alignments with long-term success measures, and specific/non-species job and abilities management evaluations can lead to better working partnerships. Education should follow the necessary pay and preparation policies (Abdullah, 2014).

Hotel staff is traditionally considered the lowestpaid employers by jobs in other sectors because they lack syndical resources and expertise (Simon \& Enz, 1995). They noticed that the financial and educational benefits given to staff would minimize moving in the hotel business. The results are low motivation, frustration with the jobs, high employee sales, and ultimately unsatisfied clients, as do workers who are frequently underpaid and undertrained. The hotel industry lacks high-quality human capital, and workers do not want to remain at the hotel's front office because of the work pressures, poor pay, and unclear prospects for advancement. The link between compensation and corporate success is greater for the management staff and motivates them to work better and is higher amongst non-managerial workers - they are attracted by a mix of rewards and rewards to improved performance (Lomban et al., 2015). If employees respect their work, they can fulfill a range of consumer demands. Employers should concentrate on strengthening their working conditions, particularly concerning wages and rewards for attracting and retaining skilled workers on all levels (Khoiriyah, 2009). Better wages and benefits are an important cause for hotel industry turnover. If the company provides advancement and fair pay, workers will be less likely to leave the organization (Suak et al., 2017).

Argyris (1960) developed the idea of a psychological contract that applies to the two parties' responsibilities to each other between the company and workers. This means that the duty will be seen differently by any side. Rousseau (1990) defines a person's conviction as a psychological agreement based on a reciprocal interchange between the staff and the firm. Studies confirm that organizational influences, such as practicing human resources, affect employees' mental contracts and organizational consequences, have a significant role. Rousseau explained that staff arrangements with organizations, such as recruiting, recruitment, performance assessments, pay, and benefits, are based on human resource activities. They also say that it would allow organizations to build a more coherent dialog and contract administration by understanding how the 
human resources policies affect individual psychological contracts. In the collaborative phase between employees and managers, psychological contracts emerge, affected by various human resources hiring, planning, wage, and performance evaluations.

Rousseau (1990) classifies mental contracts as two kinds of contracts: first, transactional contracts for special cash trades, including rapid progression, high salaries, and pay for service; third, related contracts which provide security for long term jobs, development in the workplace, and personal problems. Many recent studies have concentrated on workers' psychological contract perspective and have underpinned the reciprocal component. The significance of employees attached to transactional obligations has an adverse impact. On their obligations to the employer and contractual actions, the employees' value attached to relationship obligations has a favorable influence.

De Cuyper et al. (2008) reported that human resources activities have a double effect on contracts. First, human resources' practice shapes workers' abilities, behaviors, and behavior, thereby affecting organizational efficiency. Secondly, human resources policies influence the success of organizations by generating strategic and operational efficiencies. The employer's contract execution leads to optimal operational results, such as corporate citizenry and corporate engagement. On the other hand, infringements of the psychological contract would lead to negatives such as absenteeism, lack of confidence in the organization, diminished engagement rate, and staff turnover intentions. Recently, the effects on employee attrition rates in organizational human resources activities have gained growing recognition. Four human resources activities are considered in the proposed strategic framework: recruiting and evaluation, preparation and development, success assessment, and rewards and benefits - the interrelated and interdependent practice of all human resources activities in this context. Practices in human resources play an important part in the communication of psychological contracts. Human resources activities are used to communicate transactional and emotional exchanges between organizations and contribute to creating psychological contracts.

\section{CONCLUSION}

Hotel attrition is commonly regarded as unavoidable by employees. This paper emphasizes that an important precedent for developing workforce turnover intentions is the need to rely on staff experiences concerning human resources management processes and policies. The practice in human resources affects a psychological contract with an employee, which affects the employee's decision to leave. Therefore, to minimize staff attrition intentions, the hotel industry shall develop human resources management strategies due to the above precursors. Human and psychological contracts and resource policies should be regularly assessed according to evolving employee requirements. For the recruiting of prospective recruits, effective recruitment and selection processes are necessary. The workers must be given systematic preparation and job growth opportunities to improve their expertise, talents, and skills, which motivates employees to remain with the firm for a longer time. The performance evaluation must be conducted regularly, and the evaluation findings shall be related to monetary and nonmonetary incentives that enhance the employee's potential performance. Wages are seen as one of the major factors for high sales of company employees; key measures should be taken to raise pay comparison rates with other service-oriented sectors. These are some very important but promising steps to maintain and establish working relationships among employees. The system design offers a means of empirically testing the framework for human resource analysts, and human resource experts may use those management techniques to minimize employee turnover costs. Further explanations for psychological contracts are promising for interpreting both staff and managers' working relationships in terms of both their substance and procedures with different methodologies and realms and circumstances.

\section{REFERENCES}

[1] Abdullah, M. R. (2014). Manajemen Dan Evaluasi Kinerja Karyawan.

[2] Anggito, A., \& Setiawan, J. (2018). Metodologi Penelitian Kualitatif. CV Jejak (Jejak Publisher).

[3] Argyris, C. (1960). Understanding Organizational Behavior. Homewood III: The Dorsey Press, Inc.

[4] Ariana, I. W. T., \& Riana, I. G. (2013). Pengaruh Kepemimpinan, Kompensasi dan Displin Kerja Terhadap Kinerja Karyawan Pada Hotel Cendana Resort \& Spa Ubud, Gianyar. EJurnal Manajemen, 2(1).

[5] Arif, M. (2018). Analisis Rekrutmen dan Penempatan Kerja terhadap Kinerja Karyawan pada Hotel Oase. Al-Hikmah: Jurnal Agama Dan Ilmu Pengetahuan, 15(1), 42-63. 
[6] Bahri, S. (2019). Pengaruh Penempatan, Motivasi, Dan Lingkungan Kerja Terhadap Kinerja Pegawai. Maneggio: Jurnal Ilmiah Magister Manajemen, 2(1), 16-30.

[7] Catio, M. (2020). Manajemen Sumber Daya Manusia. Indigo Media.

[8] Choi, Y., \& Dickson, D. R. (2009). A Case Study in to the Benefits of Management Training Programs: Impacts on Hotel Employee Turnover and Satisfaction Level. Journal of Human Resources in Hospitality \& Tourism, 9(1), 103-116.

[9] D'Annunzio-Green, N., Maxwell, G., Watson, S., \& Baum, T. (2008). Implications of Hospitality and Tourism Labour Markets for Talent Management Strategies. International Journal of Contemporary Hospitality Management.

[10] De Cuyper, N., De Jong, J., De Witte, H., Isaksson, K., Rigotti, T., \& Schalk, R. (2008). Literature Review of Theory and Research on The Psychological Impact of Temporary Employment: Towards A Conceptual Model. International Journal of Management Reviews, 10(1), 25-51.

[11] Krakover, S. (2000). Partitioning Seasonal Employment in The Hospitality Industry. Tourism Management, 21(5), 461471.

[12] Lomban, M. C., Mandey, S., \& Walangitan, M. D. (2015). Pengaruh Motivasi, Upah dan Disiplin Kerja Terhadap Kinerja Pegawai Di Kantor Catatan Sipil Manado. Jurnal EMBA: Jurnal Riset Ekonomi, Manajemen, Bisnis dan Akuntansi, 3(1).

[13] Masrukhin, M. A. (2014). Praktik Sistem Kerja Berkinerja Tinggi terhadap Komitmen Afektif dengan Mediasi Keadilan Prosedural. JDM (Jurnal Dinamika Manajemen), 5(1).

[14] Mujiati, N. W., \& Dewi, A. A. S. K. (2016). Faktor-Faktor yang Menentukan Intensi Turnover Karyawan dalam Organisasi. In Forum Manajemen STIMI Handayani Denpasar (Vol. 14, No. 2, pp. 56-63)

[15] Nathalia, T. C. (2010). Prospek Pengembangan Karir Terhadap Intensi Turnover Karyawan pada Industri Perhotelan. Hospitour Volume I, (1).

[16] Ridlo, I. A. (2012). Turnover karyawan "Kajian literatur". Surabaya: $\quad P H \quad$ Movement Publication.

[17] Rohida, L. (2018). Pengaruh Era Revolusi Industri 4.0 Terhadap Kompetensi Sumber Daya Manusia. Jurnal Manajemen Dan Bisnis Indonesia, 6(1), 114-136.
[18] Rousseau, D. M. (1990). New Hire Perceptions of Their Own and Their Employer's Obligations: A Study of Psychological Contracts. Journal of Organizational Behavior, 11(5), 389-400.

[19] Ruky, A. S. (2002). Sistem Manajemen Kinerja. Gramedia Pustaka Utama.

[20] Santhanam, N., Kamalanabhan, T. J., Dyaram, L., \& Ziegler, H. (2017). Impact of Human Resource Management Practices on Employee Turnover Intentions. Journal of Indian Business Research.

[21] Sharma, B., \& Gursoy, D. (2018, June). HRM Practices in Hospitality and Tourism Industry: A Review of The Literature. In 8th Advances in Hospitality and Tourism Marketing and Management (AHTMM) Conference (p. 28).

[22] Sharma, B., \& Gursoy, D. (2018, June). HRM Practices in Hospitality and Tourism Industry: A Review of The Literature. In 8th Advances in Hospitality and Tourism Marketing and Management (AHTMM) Conference (p. 28).

[23] Simatupang, D. K., Sugiarto, E. M., \& Widjaja, D. C. (2018). Faktor-Faktor yang Mempengaruhi Turnover Intention Job Hopper di Industri Perhotelan Di Indonesia. Jurnal Hospitality dan Manajemen Jasa, 6(2).

[24] Simons, T., \& Enz, C. A. (1995). Motivating Hotel Employees: Beyond The Carrot and The Stick. Cornell Hotel and Restaurant Administration Quarterly, 36(1), 20-27.

[25] Sinambela, L. P. (2021). Manajemen Sumber Daya Manusia: Membangun Tim kerja yang solid untuk meningkatkan kinerja. Bumi Aksara.

[26] Suak, R., Adolfina, A., \& Uhing, Y. (2017). Pengaruh Reward dan Punishment terhadap Kinerja Karyawan Sutanraja Hotel Amurang. Jurnal EMBA: Jurnal Riset Ekonomi, Manajemen, Bisnis dan Akuntansi, 5(2).

[27] Sugiyono, S. (2010). Metode Penelitian Kuantitatif dan Kualitatif dan $R \& D$. Bandung: Alfabeta.

[28] Wahyuni, A. S., Zaika, Y., \& Anwar, R. (2015). Analisis Faktor-Faktor yang Mempengaruhi Turnover Intention (Keinginan Berpindah) Karyawan pada Perusahan Jasa Konstruksi. Rekayasa Sipil, 8(2), 89-95.

[29] Widyantara, I. B. P., \& Ardana, I. K. (2015). Pengaruh Kepuasan Kerja dan Komitmen Organisasi Terhadap Intensitas Turnover Karyawan. E-Jurnal Manajemen, 4(6).

[30] Yoety, O. A. (2008). Ekonomi Pariwisata: Introduksi, Informasi, dan Aplikasi. Penerbit Buku Kompas. 